\title{
Geological Society of China: Spreading geological knowledge among teenagers
}

\begin{abstract}
The Geological Society of China pays great attention to the popularization of geological knowledge among teenagers. The Committee on Popularization for Geosciences was set up by the Society. and is responsible for spreading the knowledge of the geological sciences to the public, especially teenagers, in various forms such as geoscience summer camps, quiz games, article competitions, reading groups, popular science courses, training courses, popular science exhibits, and popular science books. In the last 14 years, camp participants have totaled about 109,740, have written about 103,830 geological papers, and have collected about 336,400 specimens. Many of the participants have become interested in geology and have majored in it as a result. The Geological Society of China has accomplished a lot in training successors to its cause and in raising the cultural level of the nation.
\end{abstract}

Chinese geological scientists have always paid great attention to disseminating geological knowledge among teenagers. As early as the 1950s, they began to organize various seminars on the geological sciences in middle schools and, at the same time. to encourage students from the geological colleges to go to the middle schools in order to spread their love of geology there. However, only since the establishment of the Geological Society of China's Committee on Popularization for Geosciences in 1980 has the planned massive dissemination of geological knowledge expanded among teenagers. The committee is affiliated with the National Geological Museum. and the Honorary Curator of the museum. Gao Zhenxi, was appointed the first Chairman of the committee. The current committee is in its second term of office. At the same time as the establishment of the committee. Provincial committees were created in 30 Provinces for the purpose of popularizing the geosciences. Thus. a complete geological network was formed for this purpose at levels varying from central to local authorities. These authorities mutually coordinate their activities throughout the whole country. The main goal of the Geological Society of China's work in promoting learning about geology is to serve teenagers. as discussed in this article.

\section{Organizing geological summer camps for teenagers}

Summer camps are a good way to spread geological knowledge among teenagers by liberating them from being tightly closed in classrooms for long times and by letting them fully enjoy the beautiful scenary of nature. At summer camps, the teenagers may relax and also learn a lot about geology that cannot be learned in classrooms. Many campers never have suspected that a piece of rock or fossil, a mountain peak, or a small brook may contain such wonderful geological common sense. These camps always have strongly attracted many teenagers because of their rich content of activities.

Geological summer camps have been organized 14 times successively from 1978 to 1991 (see table 1). In this time, more than 109,000 teenagers throughout China have participated in these and have been greatly influenced scientifically.

The Geological Society of China was one of the earliest societies to organize scientific summer camps for teenagers in this country, and under its influence, several tens of national societies of the natural sciences have held their own summer camps here. Scientific summer camps now have become a traditional way to disseminate professional scientific knowledge from natural science societies to teenagers.

\section{Structure of summer camps}

Before 1981, the Geological Society of China was responsible for the organization of summer camps. In 1981, the Ministry of Geology and Mineral Resources decided to cooperate with the Geological Society of China in order to hold geological summer camps jointly throughout China, and summer camps since then have been named officially "All-China Geological Summer Camps for Teenagers." Three levels of summer camp headquarters are in place, and these are the National Summer Camp Headquarters, the Provincial Summer Camp Headquarters. and the branch summer camp headquarters under each Provincial Summer Camp Headquarters. These headquarters have their own directors. deputy directors, and scientific advisors. The leaders of the National Summer Camp Headquarters are the Minister and Deputy Minister of Geology and Mineral Resources. the President and a Vice-President of the Geological Society of China, and the Chairman of the Committee on Popularization for Geosciences of the Society. The leaders of the Provincial Summer Camp Headquarters are the Directors or their deputies of the Provincial Bureaus of Geology and Mineral Resources and the Presidents and VicePresidents of the Provincial geological societies.

Every Provincial camp headquarters has one to several branch summer camp headquarters under it, and each branch has its own campground. For example, in 1986 the National Geological Summer Camp Headquarters had 29 Provincial summer camps and 102 branch summer camps. The office of the national headquarters is affiliated with the National Geological Museum at Funei Dajie 64. Xisi, Beijing. China. and is run by the Committee on Popularization for Geosciences of the Society. The offices of the Provincial headquarters are run by Committees on Popularization for Geosciences of the Provincial geological societies. Finally, each branch summer camp is composed commonly of about 100 members who make up teams composed of 10 people.

An important problem of the summer camps is how to recruit campers. The office of the National Summer Camp Headquarters is responsible for determining the membership of the geological science 
Table 1.-Geoscience summer camps held for teenagers in China from 1978 to 1991

\begin{tabular}{ccrrrr}
\hline Year & $\begin{array}{c}\text { Number of } \\
\text { Provincial camps }\end{array}$ & $\begin{array}{c}\text { Number of } \\
\text { campgrounds }\end{array}$ & $\begin{array}{c}\text { Number of } \\
\text { campers }\end{array}$ & $\begin{array}{c}\text { Number of } \\
\text { papers }\end{array}$ & $\begin{array}{c}\text { Number of } \\
\text { specimens }\end{array}$ \\
\hline 1978 & 1 & 1 & 260 & 250 & 1,300 \\
1979 & 3 & 3 & 620 & 600 & 2,400 \\
1980 & 9 & 9 & 1,200 & 1,180 & 3,600 \\
1981 & 22 & 30 & 3,100 & 3,000 & 6,000 \\
1982 & 29 & 84 & 9,750 & 9,800 & 30,000 \\
1983 & 29 & 131 & 13,540 & 13,000 & 50,000 \\
1984 & 26 & 97 & 10,000 & 10,000 & $40,000^{1}$ \\
1985 & 28 & 102 & 9,860 & 9,700 & 40,100 \\
1986 & 29 & 99 & 10,000 & 10,000 & $35,000^{2}$ \\
1987 & 28 & 132 & 11,000 & 10,500 & 40,000 \\
1988 & 26 & 95 & 7,190 & 9,000 & $20,000^{3}$ \\
1989 & 26 & 130 & 12,000 & 10,000 & 18,000 \\
1990 & 29 & 120 & 10,720 & 9,800 & $30,000^{4}$ \\
1991 & 28 & 1,119 & 109,740 & 103,830 & 336,400 \\
Totals & 313 & & & & \\
\hline
\end{tabular}

Summer camps known as Salute to Northwest China Builders were organized.

${ }^{2}$ Summer camps known as Salute to Builders in Coastal Areas were organized.

${ }^{3}$ Summer camps for teenagers from both sides of Taiwan Strait were organized.

${ }^{4}$ Summer camps known as Love for China were organized.

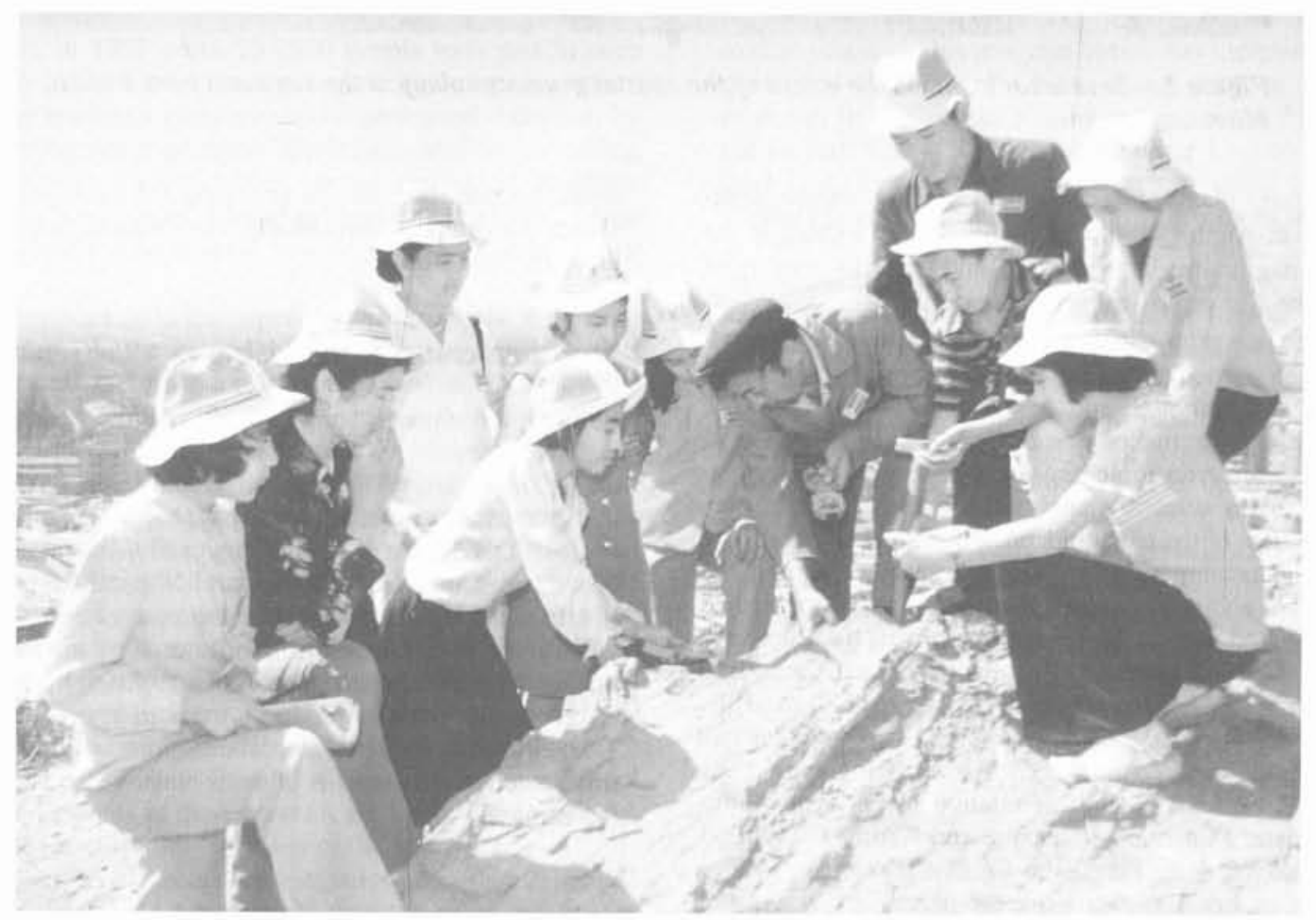

Figure 1.-Camp counselor teaches summer campers how to use a geological compass on a rock outcrop in the suburbs of Urïmqi, Xinjiang Uygur Autonomous Region, China.

summer camps. In order to become a member of the camp, one should be first a good pupil in school. Because there are no permanent memberships in summer camp, the directors of the schools make recommendations every year regarding membership.

\section{Summer camp activities}

The activities of the geological summer camps are plentiful and colorful and include not only scientific activities but cultural and sports activities as well. However, the scientific activities are mainly geological in nature, such as outdoors field geology excursions (fig. 1) and specimen collecting trips. Indoor activities include visits to local geological museums, natural science museums, geological education and research institutions, computer centers, and seismological stations, for example. In addition, meetings are organized for the campers and geoscientists who lecture on various topics of interest to the campers. Other kinds of scientific activities include studies on 


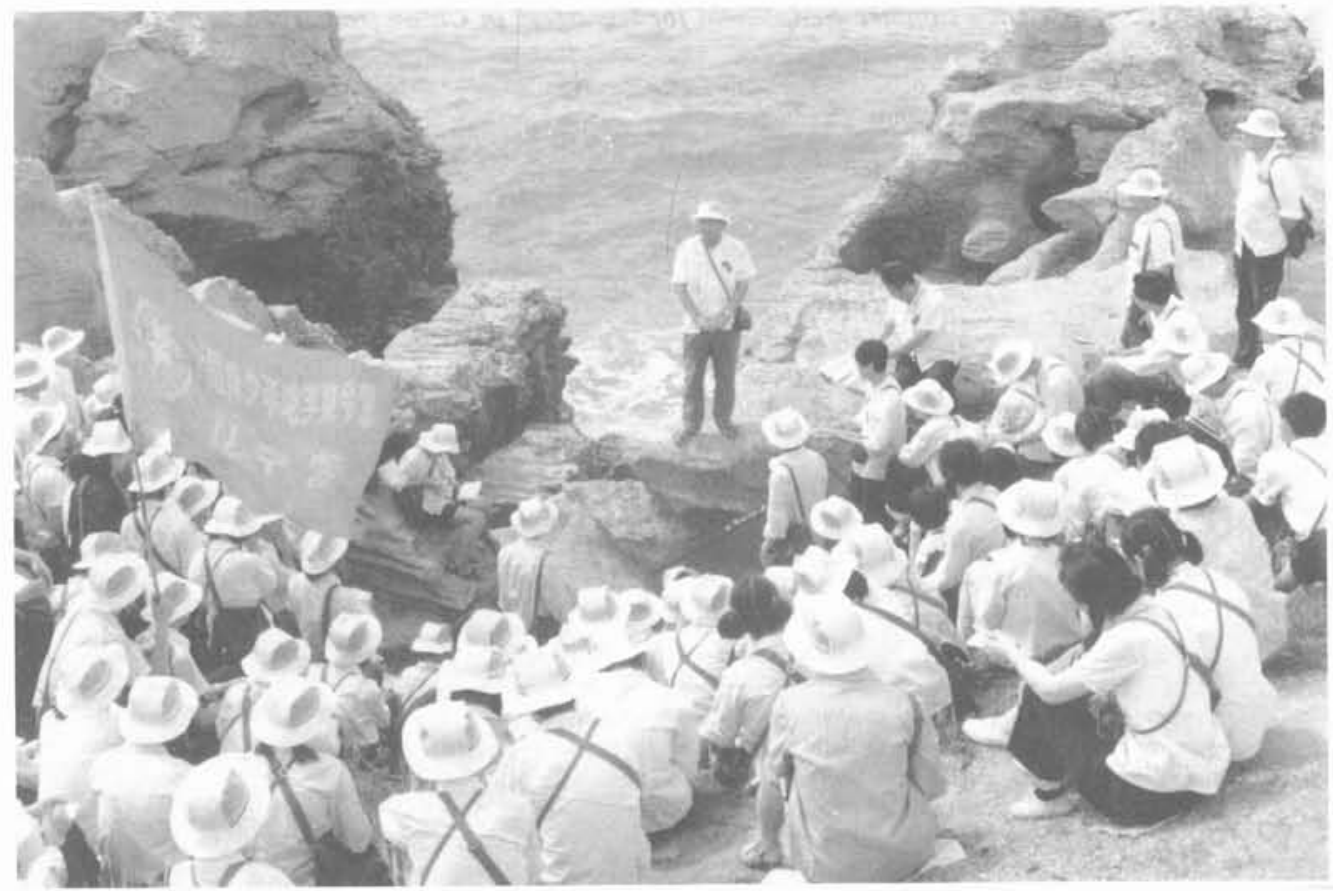

Figure 2.-Instructor explains the origin of the coastal geomorphology at the sea coast near Dalian, Liaoning Province, China.

vegetation cover, farm plants, insects, climate, astronomical observations, and the like. Almost all the campgrounds are located in the vicinity of famous mountains, large streams, and beautiful scenery or at places having specific geological phenomena (fig. 2)

At the end of each term of summer camp activities, the headquarters request each participant to prepare a short paper on geology as a summary of the activities and to collect a set of geologic specimens. After a camper makes observations on a geologic phenomenon, he or she selects a topic and takes notes on the observations that are based on scientific analysis and the student's own understanding and view of the phenomenon. The excellent papers are presented to the whole summer camp. During the various camps, the campers have written about 103,830 papers, and we have published four volumes of selected papers. The topics of many of these are very fresh and original, as, for example, "Why Fish and Leaf Came Into Stones," "Why Sea Water Is Bitter and Salty," "Where Did the Hills and Water of the Summer Palace Come From?," "Why Songshan Mountain Is So High," "I Like Andesite," "An Autobiographic Note of a Piece of Rock Itself-A Record of Granite of Panshan Mountain," "Beautiful Sister Minerals - Malachite and Azurite," "When I Grow Up, I Want to Work on Petroleum for Our Motherland." The words and expressions used in most of these papers are very vivid and full of the flavor of children, but their capability for understanding geologic phenomena is amazing. Many of these papers have reached the level of freshmen papers written by geological colleagues in China, and the campers always have welcomed the preparation of these. In addition, some campgrounds hold competitions for the exhibition of specimens collected by campers, and awards are given for the specimens collected and to the excellent specimen collectors. The specimens then are brought back to the campers' schools, where they become very useful teaching materials.

In order to ensure the success of the popularization of the geological sciences at the summer camps, every branch summer camp headquarters first should organize summer camp activity counselors to make preliminary surveys of the itineraries of field excur- sions. Second, they should print detailed geological teaching materials for the campers. And finally, they should determine the activities for each field stop.

\section{Summer camp fundraising}

Before the summer campers arrive at the campgrounds, all their expenses are paid by the campers themselves or by the organizations that sponsor them. After they arrive, the expenses for lodging, board, transportation, and facilities are paid by the organizers of the summer camps. The Ministry of Geology and Mineral Resources and the Provincial Bureaus of Geology and Mineral Resources provide special funds to summer camps in the sum of about $300,000-500,000$ yuan every year. Therefore, the funds for these camps are provided mainly by governmental departments. In addition, we make every effort to get financial support from mines, industrial enterprises, local education departments, labor unions, youth leagues, and scientific societies. The parents of the teenagers also are willing to support the camps.

\section{Other scientific activities for teenagers}

In addition to the geological summer camps that are held once a year, we frequently support other forms of activities to promote learning about geology. These activities include the establishment of groups and associations for those interested in geology, national seminars on geology for teenagers, competitions on geological knowledge for teenagers, and contests on ways to solve actual geological problems.

First, we have established groups and associations for teenagers who are interested in geology. As early as in 1978, the Geological Society of Beijing helped six middle schools in Beijing establish 
groups for lovers of geology. The Society sends geoscientists to instruct the activities of these groups, and the geography teachers in the middle schools are responsible for the organizational work. In general. each group is composed of about 10 students. If more students want to join a group, the school may establish several such groups according to grade. The group continues its scientific activities throughout the year and generally meets once every week or two. The group also organizes field excursions during the winter, spring. and summer vacations. Currently. geology-lovers groups have been established in more than 100 middle schools and have more than 600 nembers. Additionally. Provincial associations have been created for teenagers, and about 5.000 members actively participate in their geological activities all year round.

Second, national seminars on geology have been held for teenagers since 1979. The China Association for Science and Technology has organized a series of seminars for teenagers and has published selected papers afterward. These seminars have been very well received by teenagers who are fascinated by geology.

Third, teenagers compete with one another in the field of geological knowledge. Because of teenagers thirst for knowledge and their special psychology of striving for victory. competitions based on geological knowledge are organized in two forms. One is competition in written form through the use of newspapers, and the other is competition through the use of television, where thousands and even hundreds of thousands of geology lovers participate in the competition. For instance, in 1987 about 297.000 people took part in such competitions. To be a winner in the competition. one needs to prepare overall by reading a great amount of geological literature, by examining and recognizing geologic specimens. and by consulting geologists and geology teachers about various geological problems through which they have gained a lot of geological knowledge. These competitions are really a wonderful way to spread this knowledge among teenagers.

Fourth, contests are held for papers by teenagers about ways to solve actual problems in the geological sciences. The contests are a form of competition put forth for the first time in China by the Geological Society of China. The papers presented should contain ways to solve (countermeasures for) an actual problem that exists. This is really a contest that also may be called a competition of applied papers. The first contest of countermeasure papers in the geological sciences was held in 1985, and its general theme was "Planning of Land Investigations and Control." Under this were five subthemes consisting of suggestions on "Planning of Land Investigations and Control": suggestions on "Mineral Resources Investigations and Development"; suggestions on "Waterpower Resources Investigations and Development"; suggestions on "Tourist Resources Investigations and Development"; and "Planning of Townships. Factories and Plants, Mines, Township Streets. Camp Bases, and School Gardens." The participants in these contests are limited to geoscience enthusiasts in the broader 14- to 30-year-old age group. All the papers should be based on practical investigations and should include plans for solving the particular subjects that are proposed by the organizers of the contest. Some papers even include estimates of the cconomic effects of particular projects.

\section{Results of popularizing geology among teenagers}

According to incomplete statistics from the past 14 years, hundreds of thousands of teenagers have participated in the activities organized by the Geological Society of China and its branches. The number of teenagers who also were influenced indirectly by these activities may amount to a hundred times this total. Needless to say, these activities have greatly expanded the influence of the geological sciences in China. We estimate that the participating teenagers have written more than 103.000 geoscientific papers or theses, have collected more than 336,000 pieces of various geologic specimens, and have provided geologic specimens to thousands of middle schools for teaching purposes.

Because of the popularization of the geological sciences. many teenagers have become interested in geology and, furthermore, have decided to serve the people through geological work for the rest of their lives. In recent years, the number of young people who have taken exams for geological colleges obviously has increased. In 1977 when the four geological colleges recruited students in Beijing. not a single candidate had a geological college as a first choice. In 1978 and 1979 as well, only a few students submitted their names for exams to enter a geological college, and this situation worried the Chinese geological community greatly. Through careful analysis, we concluded that young people did not take exams for geological colleges because they knew very little or nothing about the geological sciences. Only if we were to strengthen the knowledge of geology among teenagers could we change this unfavorable situation.

As a result of the establishment of the Committee on Popularization for Geosciences under the Geological Society of China in 1980, an extensive and well-organized program to disseminate information about the geosciences was conducted for teenagers in the middle schools. This program in turn has increased enrollments in the geological colleges of China. If we look at Beijing City as an example. in 1982 more than 50 percent of the freshman recruited by the Department of Geology of Beijing University took geology as their first choice. In 1983 the four geological colleges recruited 41 students from 570 candidates taking geology as their first choice, and in 1984 the four geological colleges recruited 34 students from 510 candidates taking geology as their first choice. In addition, many of the freshmen enrolled in geology at the various universities or geological colleges used to be active participants in the teenagers" activities organized by the Geological Society of China.

Naturally, the popularization of any science should have as a goal not only that of making young people successors to its cause but also that of raising the cultural level of the whole nation, as well as raising the level of the entire human race. We are unable (and should not try) to make all young people geoscientists, but every one of us must provide rudimentary geological knowledge to as many young people as possible. From the point of view of a national geological community, the Geological Society of China would like geoscientists all over the world to join together in spreading geological knowledge to the total human society. Through such an effort. we will contribute to the enhancement of scientific civilization on behalf of all human beings. $\square$

Chen Anze, a Senior Geologist and an expert on tourism geology, is the Deputy Secretary General of the Geological Society of China and the Chairman of the Committee on Popularization for Geosciences. He has made great contributions to the promotion of geoscience among teenagers. His published papers include "Texture and Tec. tonics of Magmatic Rocks" and "An Introduction to Tourist Geology, " among others. 